\title{
PERAMALAN PENJUALAN MINUMAN TRADISIONAL BANDREK DI CV. CIHANJUANG INTI TEKNIK, CIMAHI, JAWA BARAT (Studi Kasus pada Penjualan Bandrek Tahun 2013)
}

\author{
Helen A Sianturi, dan Kuswarini Kusno
}

Program Studi Agribisnis, Fakultas Pertanian, Universitas Padjajaran E-mail: helen_sianturi@yahoo.com; rinipiano@yahoo.co.id

\begin{abstract}
ABSTRAK. Bandrek merupakan minuman tradisional khas Jawa Barat yang terbuat dari berbagai campuran rempah-rempah. Seiring berjalannya waktu dan disesuaikan dengan kebutuhan masyarakat, saat ini bandrek telah tersedia dalam bentuk kemasan siap saji. Salah satu perusahaan yang memproduksi bandrek kemasan adalah CV. Cihanjuang Inti Teknik yang berlokasi di Cimahi, Jawa Barat. Berdasarkan data penjualan perusahaan selama 3 tahun terakhir diketahui terjadi fluktuasi penjualan bandrek setiap bulannya, sehingga perlu dilakukan peramalan untuk memprediksi penjualan bandrek satu tahun mendatang. Tujuan yang ingin dicapai dari penelitian ini adalah untuk menganalisis peramalan penjualan minuman tradisional bandrek untuk satu tahun ke depan dari Juni 2014 hingga Mei 2015 di CV. Cihanjuang Inti Teknik. Penelitian ini menggunakan analisis kuantitatif, dengan teknik penelitiannya adalah studi kasus. Analisis kuantitatif digunakan untuk meramalkan penjualan bandrek. Data yang dipergunakan dalam peramalan adalah data penjualan selama tiga tahun terakhir dari Juni 2011 hingga Mei 2014. Metode yang digunakan untuk meramalkan penjualan adalah metode eksponensial linier, metode dekomposisi, dan metode ARIMA dengan bantuan Microsoft Excel dan Minitab 17. asil penelitian ini menunjukkan bahwa peramalan dengan ketiga metode tersebut menunjukkan hasil yang berbeda-beda. Hasil peramalan yang menggunakan metode eksponensial linier menunjukkan bahwa penjualan meningkat 9,6\% dengan nilai kesalahan MSE 510966679, yang menggunakan metode dekomposisi, penjualan meningkat 18,6\% dengan nilai MSE 1564450485 sedangkan yang menggunakan metode ARIMA $(0,1,1)$, penjualan turun $9,4 \%$ dengan nilai MSE 876651753 . Hasil ini dapat digunakan perusahaan sebagai dasar perencanaan dan pengambilan keputusan.
\end{abstract}

Kata kunci: Bandrek, MinumanTradisional, Peramalan, Penjualan.

\section{FORECASTING SALES Bandrek IN TRADITIONAL DRINKS CV. CIHANJUANG CORE ENGINEERING , CIMAHI, WEST JAVA (Studies Case Bandrek sales in 2013 )}

\begin{abstract}
Bandrek is a special traditional beverage from West Java made from various mixtures of spices. Being adjusted to the needs of the society over time, now bandrek are available in instant packages. One of the companies producing packaged bandrek is CV. Cihanjuang Inti Teknik. Based on the sales data during the last 3 month, there happened to be sale fluctuations every month. Thus, forecasting to predict the sales of bandrek in the coming year is needed. The aim of the research is to analyze forecasting of the sales of bandrek on $C V$. Cihanjuang Inti Teknik in the coming year. CV. Cihanjuang is located in Cimahi Region, West Java. This research used a quantitative analysis, along with case study technique. Quantitative analysis is used for forcasting the sales of bandrek. The sales data were collected from June 2011 to May 2014. The method used for forecasting sales is method exponential linier, method decomposition, and method ARIMA with the use of Microsoft Excel and Minitab 17. The results of the research indicate that the forecasting results of the three methods showed different results. The forecast using linear exponential sales shows that the sales increased $9.6 \%$ with a value of 510966679 error MSE, while the decomposition method shows that the sales increased 18.6\% to the value of MSE 1564450485, and the methods of ARIMA $(0,1,1)$ shows that sales fell 9.4\% to the value MSE876651753. These results can be used by the enterprise as a basis for planning and decision-making.
\end{abstract}

Key words: Bandrek, Forecasting, Traditional Beverage, Sales.

\section{PENDAHULUAN}

Minuman tradisional adalah minuman yang termasuk jajanan serta campuran atau bahan yang digunakan secara tradisional dan telah lama berkembang secara spesifik di daerah atau masyarakat (Yusuf, 2012). Bandrek merupakan minuman tradisional khas Jawa Barat. yang terbuat dari berbagai campuran rempah-rempah seperti jahe, gula aren, cengkeh, pala dan lada hitam. Minuman ini disajikan hangat pada saat cuaca dingin seperti musim hujan dan malam hari, yang berfungsi untuk menghangatkan tubuh. Biasanya minuman ini dijajakan di warung dan gerobak keliling.
Seiring berjalannya waktu dan disesuaikan dengan kebutuhan masyarakat, minuman tradisional ini telah tersedia dalam bentuk serbuk siap saji sehingga dapat dengan mudah dinikmati dimana saja dan kapan saja.

Salah satu perusahaan yang memproduksi bandrek adalah CV. Cihanjuang Inti Teknik (CINTEK), berlokasi di Cimahi, Jawa Barat. Perusahaan ini merupakan salah satu UKM yang tergolong sukses di Cimahi yang menerima banyak penghargaan baik skala regional ataupun nasional, sehingga dijadikan UKM percontohan untuk UKM sekitar Cimahi. Beberapa penghargaan yang diterima CV. Cihanjuang Inti Teknik yaitu: piagam Siddhakarya sebagai perusahaan yang 
mendapatkan penghargaaan kualitas dan produktivitas klasifikasi baik di Jawa Barat tahun 2012, penghargaan Paramakarya tahun 2013 sebagai satu dari 20 UMKM di Indonesia yang telah berhasil menerapkan konsep kualitas dan produktivitas yang baik. Perusahaan ini juga sering mendapatkan kunjungan dari sekolah, universitas, kementrian dan pemerintah setempat.

Selain memproduksi bandrek, minuman tradisional lain yang diproduksi perusahaan adalah bajigur, kopi bajigur, sekoteng dan beas cikur (beras kencur), dan variasi bandrek: bandrek original, kopi bandrek, en teh bandrek (bandrek teh), bandrek spesial, cokelat bandrek. Bandrek merupakan produk unggulan dari CV. Cihanjuang Inti Teknik. Berdasarkan data penjualan tahun 2013 dapat diketahui, bandrek memberikan kontribusi penjualan terbesar dibandingkan minuman tradisional lain yang diproduksi perusahaan. Bandrek memberikan kontribusi $69 \%$ dari total penjualan, bajigur $18 \%$ dan produk lainnya $13 \%$.

Tabel 1. Penjulan Minuman Tradisional di CV. Cihanjuang Inti Teknik tahun 2013

\begin{tabular}{clcc}
\hline No & \multicolumn{1}{c}{ Produk } & $\begin{array}{c}\text { Jumlah } \\
(\text { sachet })\end{array}$ & Persentase (\%) \\
\hline 1 & Bandrek Original & 188.214 & 25 \\
2 & Bajigur Original & 120.457 & 15 \\
3 & Kopi Bandrek & 30.114 & 4 \\
4 & En Teh Bandrek & 37.643 & 5 \\
5 & Bandrek Spesial & 135.514 & 18 \\
6 & Coklat Bandrek & 127.985 & 17 \\
7 & Kopi Bajigur & 22.585 & 3 \\
8 & Sekoteng & 75.286 & 10 \\
9 & Beas Cikur & 22.585 & 3 \\
\hline & Total & 760382 & 760.382 \\
\hline
\end{tabular}

Sumber: CV. Cihanjuang Inti Teknik (2014)

Bandrek Hanjuang telah dipasarkan di berbagai daerah di Indonesia seperti: Jawa Barat, Jawa Tengah, Sumatera, Kalimantan, Bali, Papua dan juga telah menembus pasar luar negeri seperti Malaysia, Arab, Australia dan Amerika. Bentuk pemasaran yang dilakukan adalah dengan membuka agen atau distributor untuk memasarkan produk ke berbagai daerah di Indonesia. Perusahaan juga memasarkan produknya ke warung, toko, grosir dan telah tersedia di minimarket, supermarket dan swalayan.

Berdasarkan data penjualan bandrek satu tahun terakhir pada Tabel 2 dapat diketahui penjualan bandrek cenderung mengalami fluktuasi setiap bulannya. Penjualan turun memasuki bulan Juni-Juli, kemudian meningkat dari bulan Agustus-September dan naik turun memasuki bulan selanjutnya. Penjualan turun menjelang bulan puasa karena minuman ini bersifat hangat dan pedas sedangkan masyarakat lebih memilih minuman dingin dan manis ketika berbuka puasa, kemudian meningkat di bulan selanjutnya. Penjualan meningkat memasuki musim penghujan, karena minuman ini dapat berfungsi untuk menghangatkan badan dan meningkat memasuki akhir dan awal tahun.

Tabel 2. Jumlah Penjualan Bandrek Bulan JanuariDesember 2013

\begin{tabular}{lc}
\hline \multicolumn{1}{c}{ Bulan } & Jumlah Penjualan (sachet) \\
\hline Januari & 231.732 \\
Februari & 188.733 \\
Maret & 188.810 \\
April & 205.972 \\
Mei & 223.128 \\
Juni & 188.810 \\
Juli & 137.313 \\
Agustus & 187.076 \\
September & 274.634 \\
Oktober & 223.128 \\
November & 240.278 \\
Desember & 257.469 \\
\hline
\end{tabular}

Sumber: CV. Cihanjuang Inti Teknik, 2014

Penjualan bandrek yang cenderung fluktuatif mengakibatkan perusahaan sulit untuk menentukan jumlah bandrek yang akan diproduksi. Selain itu, penjualan pun menjadi tertunda sehingga terjadi penumpukan persediaan. Selama ini CV. Cihanjuang Inti Teknik memperkirakan volume penjualan berdasarkan jumlah penjualan pada tahun sebelumnya. Pada saat jumlah penjualan pada tahun sebelumnya meningkat, maka perusahaan akan meningkatkan jumlah produksi untuk memenuhi kebutuhan penjualan, tetapi pada saat jumlah penjualan menurun, perusahaan akan menurunkan jumlah produksi sehingga tidak terjadi penumpukan persediaan. Selama ini, perusahaan memperkirakan jumlah penjualan dengan menggunakan perhitungan sederhana dan intuisi pimpinan perusahaan. Cara seperti itu akan menimbulkan kemungkinan perkiraan penjualan terlalu besar atau terlalu kecil. Apabila prediksi penjualan terlalu besar, maka biaya produksi meningkat sehingga seluruh investasi yang ditanamankan menjadi kurang efisien dan resiko kerusakan bandrek menjadi lebih besar. Sebaliknya, apabila prediksi penjualan kurang atau terlalu sedikit, maka penjualan akan tertunda, dan kesempatan penjualan menjadi hilang. Oleh karena itu, agar perkiraan penjualan dapat akurat, perlu dilakukan peramalan penjualan berdasarkan analisis yang terstruktur.

Pemikiran ini sejalan dengan apa yang diikemukakan oleh Rangkuti (2005), bahwa untuk mengantisipasi permasalahan tersebut perlu dilakukan peramalan kemungkinan terjadinya penurunan dan kenaikan penjualan pada periode yang akan datang dengan memperoleh informasi yang akurat sehingga perusahaan dapat mempersiapkan strategi-strategi yang harus ditempuh dalam menghadapi kondisi tersebut. Menurut Arsyad (1999) ketidakakuratan dalam proses 
peramalan sering terjadi, tetapi peramalan masih tetap perlu dilakukan. Hal ini karena semua organisasi beroperasi dalam suatu lingkungan yang mengandung unsur ketidakpastian, tetapi keputusan harus tetap diambil yang nantinya akan mempengaruhi masa depan organisasi tersebut.

Berdasarkan uraian diatas, penulis tertarik untuk melakukan analisis mengenai peramalan penjualan bandrek di CV. Cihanjuang Inti Teknik untuk satu tahun ke depan yaitu dari bulan Juni 2014 sampai Mei 2015. Hasil analisis peramalan penjualan bandrek akan dapat berguna sebagai dasar pengambilan keputusan dan perencanaan strategi perusahaan ke depan, untuk jangka pendek dan menengah..

\section{METODE}

Penelitian ini dilaksanakan di CV. Cihanjuang Inti Teknik yang beralamat di Jl. Cihanjuang No. 34, Cimahi, Jawa Barat. Pemilihan lokasi ditentukan dengan pertimbangan bahwa $\mathrm{CV}$. Cihanjuang Inti Teknik merupakan salah satu UKM di Jawa Barat yang memproduksi minuman tradisional bandrek dengan kemasan yang menarik dan merupakan salah satu UKM yang tergolong sukses di Cimahi yang menerima banyak penghargaan baik skala regional maupun nasional Penelitian ini menggunakan analisis kuantitatif, dengan teknik penelitian studi kasus (case study). Studi kasus merupakan salah satu metode penelitian deskriptif (descriptive explanatory) yang bertujuan untuk memberikan gambaran secara mendetail tetang latar belakang, sifat-sifat serta karakter-karakter yang khas dari kasus, ataupun status dari individu, yang kemudian dari sifat-sifat khas diatas akan dijadikan suatu hal yang bersifat umum (Nazir, 2003). Studi kasus dapat menggunakan bukti baik yang bersifat kuantitatif maupun kualitatif; penelitian dengan subjek tunggal memberikan kerangka kerja statistik untuk membuat inferensi dari data studi kasus kuantitatif (Robert K. Yin, 2002). Sumber data dan informasi dalam penelitian ini terdiri dari dua jenis yaitu data primer dan data sekunder, yang diperoleh melalui wawancara, observasi dan studi literatur.

Untuk meramalkan volume penjualan bandrek, digunakan metode peramalan penjualan secara kuantitatif yaitu metode peramalan deret waktu (time series). Pertimbangannya adalah bahwa data penjualan merupakan data deret waktu; artinya data tersebut disajikan berdasarkan waktu kejadian tanpa menunjukkan faktor-faktor yang mempengaruhinya. Ada 3 macam metode untuk meramalkan penjualan bandrek untuk satu tahu ke depan, yaitu metode eksponensial linier, metode dekomposisi, dan metode ARIMA. Data yang dipergunakan dalam peramalan ini adalah data penjualan selama tiga tahun terakhir dari Juni 2011-Mei 2014.

Adapun ketiga buah metode peramalan tersebut mempunyai formula sebagai berikut:
1) Metode Eksponensial Linier: dimana hasil peramalan pada tahun $\mathrm{t}$ dengan menggunakan periode muka yang diramalkan nilai pengamatan aktual periode awal taksiran kemiringan dari serial data beberapa periode

2) Metode Dekomposisi: dimana

: komponen musiman pada periode $\mathrm{t}$

: komponen trend pada periode $\mathrm{t}$

: komponen siklus pada periode $\mathrm{t}$

: kesalahan pada periode $\mathrm{t}$

3) Metode ARIMA: ARIMA (p, d, q) dimana

$\mathrm{p}$ : angka untuk autoregressive $(A R)$

$\mathrm{d}$ : angka untuk order differencing

$\mathrm{q}$ : angka untuk moving average (MA)

Tingkat akurasi hasil peramalan ditentukan oleh tingkat kesalahan peramalan, yaitu ukuran tentang perbedaan hasil peramalan tingkat penjualan dengan tingkat penjualan yang sebenarnya terjadi. Semakin kecil nilai kesalahan peramalan maka metode peramalan semakin akurat. Dalam penelitian ini, untuk menghitung nilai kesalahan peramalan digunakan kriteria MSE (Mean Squared Error), yang formulanya adalah: (Assauri, 1984)

$\mathrm{MSE}=$ dimana: jumlah kuadrat dari selisih nilai yg sebenarnya dengan nilai pengamatan aktual (penyimpangan); $\mathrm{i}=1,2, \ldots, \mathrm{N}$

$\mathrm{N}$ : banyak data $=36$ (data penjualan selama 36 bulan)

Nilai MSE menunjukkan kesalahan peramalan. Dengan demikian, metode yang menghasilkan nilai MSE terkecil akan merupakan metode yang paling akurat. Pemilihan MSE sebagai pengukur kesalahan peramalan ini sesuai pula dengan pendapat Render dan Heizer (2001), yang menyatakan bahwa menggunakan MSE sebagai penghitung kesalahan peramalan biasanya lebih baik karena meliputi beberapa penyimpangan yang kecil. Pengolahan data dalam penelitian ini dilakukan dengan bantuan program Microsoft Excel dan Minitab 17.

\section{HASIL DAN PEMBAHASAN}

\section{Konsep Peramalan dan Dasar Pembandingan Ketiga Buah Metode Peramalan Penjualan Bandrek}

Menurut Prasetya, Herry, dan Lukiastuti (2009), peramalan adalah seni dan ilmu yang memperkirakan kejadian di masa depan; hal ini dapat dilakukan dengan melibatkan pengambilan data masa lalu dan menempatkan ke masa yang akan datang dengan suatu model matematis. Kegunaan dari peramalan terlihat pada saat pengambilan keputusan. Keputusan yang baik adalah keputusan yang didasarkan pada pertimbangan apa yang akan terjadi pada waktu keputusan itu dilaksanakan. Dalam suatu perusahaan, ramalan dibutuhkan untuk memberikan informasi kepada pimpinan sebagai dasar 
untuk membuat keputusan dalam berbagai kegiatan, seperti penjualan, permintaan, persediaan keuangan, dan sebagainya (Assauri, 1984)

Makridakis, Wheelwright and Mc.Gee (1991) menyatakan kebutuhan akan peramalan meningkat sejalan dengan usaha manajemen untuk mengurangi ketergantungannya pada hal-hal yang belum pasti. Peramalan menjadi ilmiah sifatnya dalam menghadapi lingkungan manajemen. Karena setiap bagian organisasi berkaitan satu sama lain, baik buruknya ramalan dapat mempengaruhi seluruh bagian organisasi.

Beberapa bagian organisasi dimana peramalan kini memainkan peranan yang penting adalah:

1. Penjadwalan sumberdaya yang tersedia. Penggunaan sumberdaya yang efisien, memerlukan penjadwalan produksi, transportasi, kas, personalia dan sebagainya. Input yang penting untuk penjadwalan seperti itu ramalan tingkat permintaan untuk produk, bahan, tenaga kerja, finansial dan jasa pelayanan

2. Penjadwalan sumberdaya tambahan. Waktu tenggang (lead time) untuk memperoleh bahan baku, menerima pekerja baru, atau membeli mesin dan peralatan dapat berkisar antara beberapa hari sampai beberapa tahun. Peramalan diperlukan untuk menentukanm kebutuhan sumberdaya di masa mendatang

3. Penentuan sumberdaya yang diinginkan. Setiap organisasi harus menentukan sumberdaya yang dimiliki dalam rangka jangka panjang. Keputusan semacam itu bergantung pada kesempatan pasar, faktorfaktor lingkungan dan pengembangan internal dan sumberdaya finansial, manusia, produk dan teknologis. Semua penentuan ini memerlukan ramalan yang baik yang dapat menafsirkan pendugaan serta membuat keputusan yang tepat.

Menurut Herjanto (2004) peramalan berdasarkan horizon waktu dikelompokkan sebagai berikut:

1. Peramalan jangka panjang, yaitu yang mencakup waktu lebih besar dari 24 bulan, peramalan yang diperlukan dalam kaitannya dengan penanaman modal, perencaan fasilitas, perencanaan untuk kegiatan penetian dan pengembangan.

2. Peramalan jangka menengah, yaitu antara 3-24 bulan, peramalan untuk perencanaan penjualan, perencanaan dan anggaran produksi.

3. Peramalan jangka pendek, yaitu untuk jangka waktu kurang dari 3 bulan, peramalan dalam hubungannya dengan perencanaan pembelian material, pejadwalan kerja dan penugasan.

Peramalan jangka panjang banyak menggunakan pendekatan kualitatif, sedangkan peramalan jangka menengah dan pendek menggunakan pendekatan kuantitatif. Assauri (1984) menyatakan pada dasarnya langkah peramalan yang penting adalah:

1. Menganalisis data yang lalu. Tahap ini berguna untuk pola yang terjadi pada masa yang lalu. Analisis ini dilakukan denan membuat tabulasi dari data yang lalu. Dengan tabulasi data, maka dapat diketahui pola dari data tersebut.

2. Menentukan metode yang dipergunakan. Masingmasing metode akan memberikan hasil peramalan yang berbeda. Metode peramalan yang baik adalah metode yang menghasilkan penyimpangan antara hasil peramalan dengan nilai kenyataan yang sekecil mungkin.

Dalam penelitian ini, langkah pada butir ke $1 \mathrm{di}$ atas dilanjutkan dengan membuat grafik agar pola data lebih mudah diinterpretasikan. Butir ke 2. merupakan alasan dasar mengapa alat analisis yang digunakan untuk membandingkan ketiga buah metode peramalan ini adalah MSE; dan selanjutnya membandingkan ketiga nilai MSE tersebut dengan memilih nilai MSE terkecil. Sedangkan konsep MSE nya itu sendiri merupakan konsep dasar statistika tentang penyimpangan atau kesalahan. Membuat peramalan pada intinya adalah melakukan optimasi yakni menentukan nilai maksimum atau minimum. Karena dalam membandingkan ketiga metode peramalan ini yang diperhatikan adalah variabel kesalahan, maka tentu saja secara logis kesalahan tersebut haruslah minimum.

Seperti telah dijelaskan di atas bahwa langkah pertama dalam peramalan adalah menganalisis data masa lalu, sehingga dapat diketahui bentuk pola datanya. Pola dari serangkaian data dalam serial waktu dapat dikelompokkan dalam pola dasar sebagai berikut:

1. Konstan, yaitu data berfluktuasi di sekitar rata-rata secara stabil. Polanya berupa garis lurus horizontal, terdapat dalam jangka pendek atau menengah, jarang sekali suatu variabel memiliki pola konstan dalam jangka panjang

2. Kecenderungan (trend), yaitu data dalam jangka panjang mempunyai kecenderungan, baik yang arahnya meningkat dari waktu ke waktu ataupun menurun. Pola ini disebabkan oleh bertambahnya populasi, perubahan pendapatan, dan pengaruh budaya.

3. Musiman (seasional), yaitu polanya merupakan gerakan yang berulang-ulang secara teratur dalam setiap periode tertentu misalnya tahunan, semesteran, kuartalan, bulanan atau mingguan. Pola ini berhubungan dengan faktor iklim/cuaca atau faktor yang dibuat oleh manusia.

4. Siklus (cyclical), yaitu data dipengaruhi oleh fluktuasi ekonomi jangka panjang, seperti daur hidup bisnis. Perbedaan utama antara pola musiman dan siklus adalah pola musiman mempunyai panjang gelombang yang tetap dan terjadi pada jarak waktu yang tetap, sedangkan pola siklus memiliki durasi yang lebih panjang bervariasi dari satu siklus ke siklus yang lain. 


\section{Identifikasi Pola Data}

Telah dijelaskan pada bagian sebelumnya bahwa identifikasi pola data dilakukan untuk mengetahui apakah data memiliki unsur konstan, trend, musiman atau siklis. Identifikasi ini dilakukan dengan cara membuat diagram pencar (plot) data penjualan bandrek selama tiga tahun sebelumnya, lalu mengamati polanya. Data penjualan tersebut adalah data dalam kurun waktu 3 tahun terakhir dimulai dari Juni 2011-Mei 2014. Karena satuan pengamatannya dalam bulan, maka jumlah serial data ada 36 .

Hasil dari plot data penjualan bandrek disajikan dalam Gambar 1. Berdasarkan Gambar 1 ini, dapat diketahui penjualan bandrek di CV. Cihanjuang Inti Teknik cenderung mengalami fluktuasi setiap bulan, yang terlihat dari naik turunnya grafik. Berdasarkan hasil plot data penjualan bandrek diidentifikasi bahwa data memiliki unsur trend dan musiman. Unsur trend terlihat dari data penjualan yang cenderung meningkat, dimana rata-rata penjualan meningkat sebesar 18,3 persen setiap tahunnya. Unsur musiman terlihat dari pola data yang berulang secara teratur dalam satu periode. Setiap tahun penjualan cenderung turun ketika memasuki bulan puasa dan meningkat ketika memasuki awal dan akhir tahun.

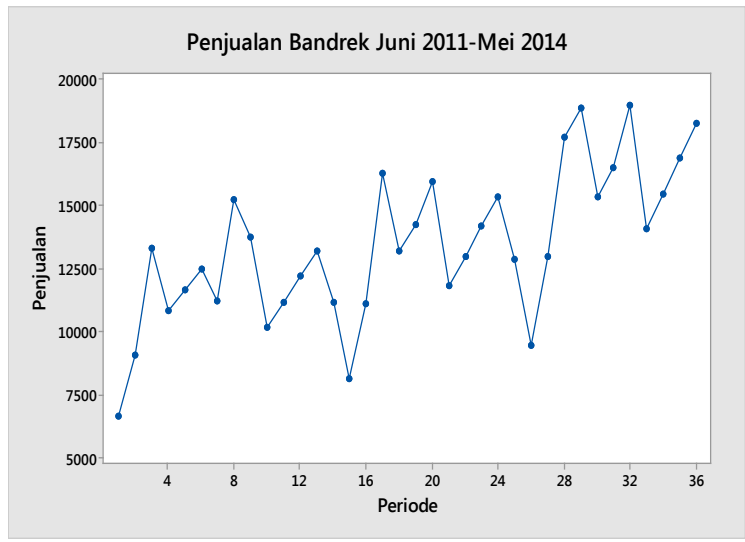

Gambar 1. Plot Data Penjualan Bandrek Bulan Juni 2011-Mei 2014

\section{Peramalan Penjualan Bandrek \\ Metode Eksponensial Linier}

Metode ini digunakan untuk serial data yang memiliki unsur trend (kecenderungan) yang konsisten, dimana nilai-nilai prakiraannya akan selalu berada di belakang nilai aktualnya (terjadi lagging yang terus menerus)

Berdasarkan hasil perhitungan menggunakan metode eksponensial linier ini diperoleh hasil penjualan bandrek untuk 12 bulan ke depan mengalami peningkatan sebesar 9,6\% dibanding tahun sebelumnya. Hasil penjualan tertinggi terjadi pada bulan Mei 2015 dengan jumlah penjualan 267.936 sachet dan penjualan terendah pada bulan Juni 2014 sebesar 233.436 sachet. Setiap bulannya penjualan diperkirakan meningkat 1,23 persen dibanding bulan sebelumnya dan untuk 12 bulan ke depan penjualan diperkirakan meningkat sebesar 9,6 persen.
Penjualan yang diperkirakan selalu meningkat setiap bulan ini berbeda dengan penjualan bandrek aktual, yang naik turun setiap bulannya. Peramalan menggunakan metode ini tidak memperhitungkan unsur musiman yang terdapat dalam data seperti penurunan yang terjadi memasuki bulan puasa, sehingga hanya terdapat kecenderungan trend yang meningkat. Oleh karena itu, perusahaan perlu mengantisipasi penjualan yang diprediksi meningkat setiap bulannya dalam membuat perencanaan, dengan cara meningkatkan persediaan bahan baku jahe, gula aren, dan creamer untuk meningkatkan produksi bandrek setiap bulan. Konsekuensinya, perusahaan perlu menyediakan anggaran untuk membeli bahan baku tersebut di atas, biaya tenaga kerja, dan untuk biaya perawatan alat serta mesin produksi, demi kelancaran proses produksi.

Tabel 3. Ramalan Penjualan Bandrek Bulan Juni 2014Mei 2015 dengan Menggunakan Metode Eksponensial Linier

\begin{tabular}{ccr}
\hline Periode & Bulan dan Tahun & Ramalan(sachet) \\
\hline 37 & Juni 2014 & 233.436 \\
38 & Juli 2014 & 236.572 \\
39 & Agustus 2014 & 239.708 \\
40 & September 14 & 242.845 \\
41 & Oktober 2014 & 245.981 \\
42 & November 2014 & 249.118 \\
43 & Desember 2014 & 252.254 \\
44 & Januari 2015 & 255.390 \\
45 & Februari 2015 & 258.527 \\
46 & Maret 2015 & 261.663 \\
47 & April 2015 & 264.800 \\
48 & Mei 2015 & 267.936 \\
\hline
\end{tabular}

\section{Metode Dekomposisi}

Metode Dekomposisi mengidentifikasi tiga komponen pola dasar yang terdapat dalam suatu serial data, yaitu komponen trend, musiman dan siklus (Herjanto, 2004). Berdasarkan hasil peramalan penjualan menggunakan metode dekomposisi, dapat diketahui penjualan bandrek untuk 12 bulan ke depan diprediksi meningkat. Penjualan akan meningkat menjelang bulan Agustus 2014-Januari 2014, kemudian turun memasuki bulan Februari 2014, dan meningkat di bulan selanjutnya. Penjualan terendah terdapat pada bulan Juli 2014 dengan jumlah 224.376 sachet dan penjualan tertinggi bulan Januari 2014 dengan jumlah 296.480 sachet. Penjualan untuk satu tahun ke depan diperkirakan naik 16,6\% dari tahun sebelumnya. Dengan demikian. hasil peramalan ini lebih besar dibandingkan dengan peramalan menggunakan metode eksponensial linier.

\section{Metode ARIMA}

Metode ARIMA merupakan suatu alat yang menggunakan nilai-nilai sekarang dan nilai-nilai 
lampau dari variabel dependen (Render dan Heizer, 2001). Berdasarkan hasil identifikasi data diketahui pola data penjualan bandrek selama 3 tahun terakhir di CV. Cihanjuang Inti Teknik tidak stasioner, oleh karena itu perlu dilakukan differencing untuk menstasionerkan data. Hasil dari differencing data terdapat pada Gambar 2.

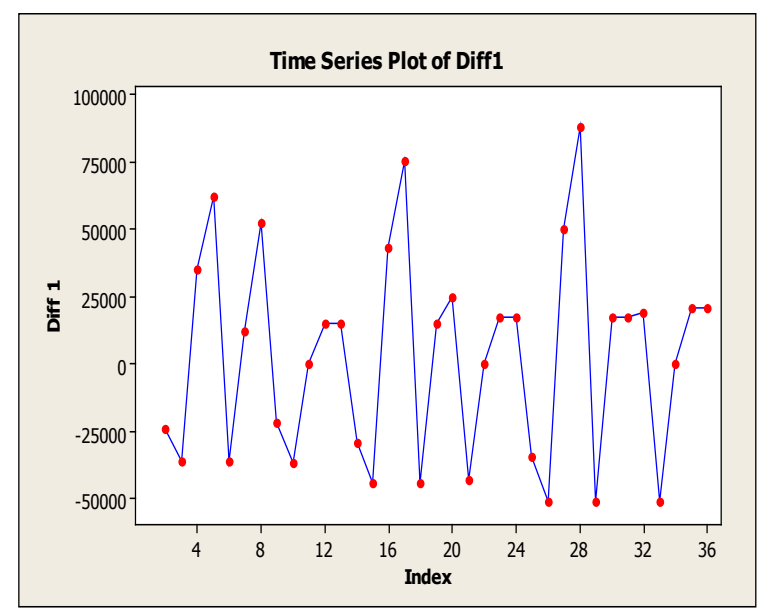

Gambar 2. Grafik Plot Data Differencing.

Berdasarkan Gambar 2, tampak bahwa data sudah stasioner, sehingga tidak perlu dilakukan differencing lagi. Dengan demikian nilai d adalah 1. Kemudian dilakukan identifikasi Autocorellation Function (ACF) dan Partial Autocorrelation Function (PACF) untuk mengetahui nilai $\mathrm{p}$ dan $\mathrm{q}$. ACF mengambarkan korelasi antara data yang sekarang dengan data sebelumnya dalam pengamatan time series. Plot ACF ini berfungsi untuk mengetahui nilai $\mathrm{p}$ pada ARIMA, dimana nilai ACF ini didapat dari jumlah lag yang terpotong pada grafik ACF.Berdasarkan grafik ACF pada Gambar 3, diketahui terdapat 1 lag yang terpotong sehingga nilai $\mathrm{p}$ adalah 1 .

Tabel 4. Ramalan Penjualan Bandrek di CV. Cihanjuang Inti Teknik Bulan Juni 2014 - Mei 2015 dengan Metode Dekomposisi

\begin{tabular}{ccc}
\hline Periode & Bulan dan Tahun & $\begin{array}{l}\text { Ramalan } \\
\text { (sachet) }\end{array}$ \\
\hline 37 & Juni 2014 & 245355 \\
38 & Juli 2014 & 224376 \\
39 & Agustus 2014 & 225428 \\
40 & September 2014 & 264451 \\
41 & Oktober 2014 & 276551 \\
42 & November 2014 & 267847 \\
43 & Desember 2014 & 278574 \\
44 & Januari 2015 & 296480 \\
45 & Februari 2015 & 274413 \\
46 & Maret 2015 & 273471 \\
47 & April 2015 & 279930 \\
48 & Mei 2015 & 295935 \\
\hline
\end{tabular}

Plot PACF (Autokorelasi Parsial) digunakan untuk mengukur tingkat keeratan hubungan antara nilai data sekarang dengan nilai data sebelumnya. Plot PACF ini berfungsi untuk mengetahui nilai q pada ARIMA, dimana nilai PACF ini didapat dari jumlah lag yang terpotong pada grafik PACF. Berdasarkan grafik PACF pada Gambar 4, terdapat 1 lag yang terpotong sehingga nilai $\mathrm{q}$ adalah 1 . Setelah nilai $\mathrm{p}, \mathrm{d}$, $\mathrm{q}$ diketahui maka didapat model ARIMA $(1,1,1)$. Model ARIMA $(1,1,1)$ ini dapat dikembangkan menjadi ARIMA $(1,1,0)$ dan ARIMA $(0,1,1)$. Untuk menentukan model ARIMA yang mana yang sebaiknya digunakan, maka dihitung MSE bagi ketiga model tersebut. Model yang memiliki nilai MSE terkecil yang harus dipilih (Render dan Heizer (2001). Ternyata model yang terpilih adalah ARIMA $(0,1,1)$, dan hasil peramalannya dapat dilihat pada Tabel 5.

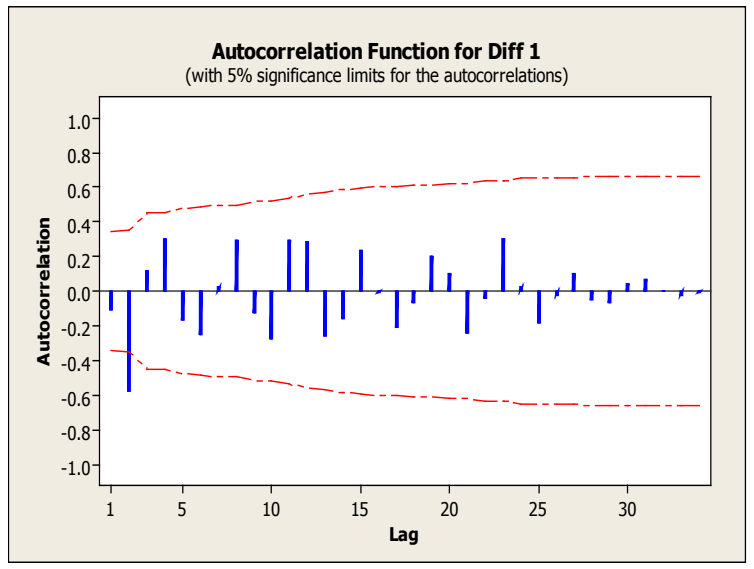

Gambar 3. Grafik Plot ACF data differencing

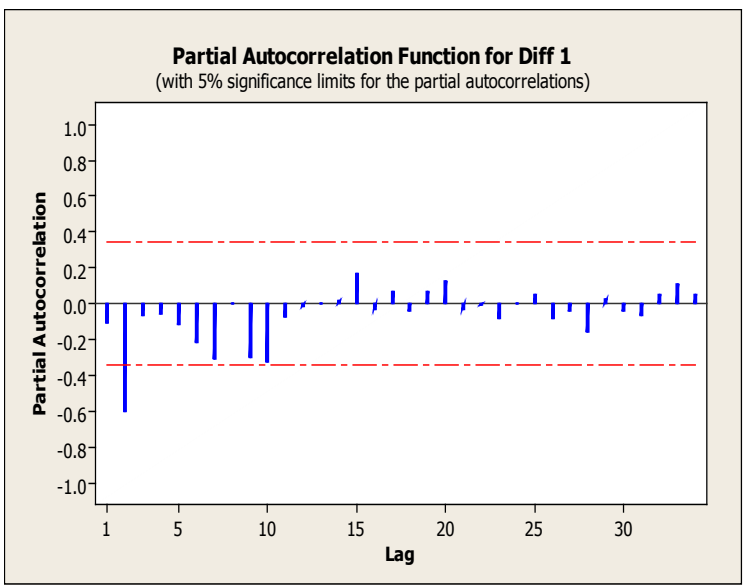

Gambar 4. Grafik Plot PACF Data differencing

Berdasarkan hasil peramalan menggunakan metode ARIMA $(1,1,0)$, diketahui penjualan untuk 12 bulan ke depan akan meningkat dari bulan Juni 2014-Mei 2015, tetapi jika dilakukan perbandingan penjualan pada tahun sebelumnnya diketahui penjualan menurun 9,4\%. Penjualan tertinggi terdapat pada bulan Mei 2015 yaitu sebesar 222.434 sachet dan terendah pada bulan Juni 2014 yaitu 191.998 sachet. rlann bulannyamenggunakan mean akan mengalami penurunan. Hasil peramalan menggunakan metode ini berbeda dengan hasil peramalan 
menggunakan dua metode sebelumnya yaitu metode eksponensial linier dan metode dekomposisi, yang mana hasil peramalan dengan kedua metode tersebut cenderung meningkat setiap bulannya.

Tabel 5. Ramalan Penjualan Bandrek di CV. Cihanjuang Inti Teknik Bulan Juni 2014 - Mei 2015 dengan Metode ARIMA $(\mathbf{0 , 1 , 1 )}$

\begin{tabular}{ccc}
\hline Periode & Bulan dan Tahun & Ramalan (sachet) \\
\hline 37 & Juni 2014 & 191998 \\
38 & Juli 2014 & 194754 \\
39 & Agustus 2014 & 197512 \\
40 & Sep-14 & 200273 \\
41 & Oktober 2014 & 203035 \\
42 & Nov-14 & 205800 \\
43 & Desember 2014 & 208567 \\
44 & Januari 2015 & 211337 \\
45 & Februari 2015 & 214108 \\
46 & Maret 2015 & 216881 \\
47 & Apr-15 & 219657 \\
48 & Mei 2015 & 222434 \\
\hline
\end{tabular}

\section{Pengukuran Kesalahan Peramalan}

Kesalahan prakiraan adalah perbedaan antara nilai variabel sesungguhnya dengan nilai prakiraan pada periode yang sama. (Herjanto, 2004). Pengukur kesalahan peramalan yang dipergunakan dalam penelitian ini adalah metode Kuadrat Tengah Kesalahan (MSE, mean squared error). Dari hasil perhitungan MSE untuk ketiga motode, diperoleh peringkat nilai MSE dari terkecil hingga terbesar sebagai berikut: peringkat pertama ditempati oleh metode dekomposisi dengan MSE senilai 510966679, kemudian peringkat ke dua terkecil ditempati oleh metode ARIMA $(1,1,0)$ dengan MSE senilai 876651753 dan metode eksponensial linier menempati peringkat ke tiga (niali MSE terbesar) dengan nilai MSE 1564450485. Dengan demikian metode yang paling akurat adalah Metode Dekomposisi, Urutan tingkat keakuratan metode dapat dilihat pada Tabel 6 .

Tabel 6. Pengukuran Kesalahan Peramalan

\begin{tabular}{lcc}
\hline Metode Peramalan & $\begin{array}{c}\text { Kesalahan Peramalan } \\
\text { (Nilai MSE) }\end{array}$ & $\begin{array}{c}\text { Urutan } \\
\text { Keakuratan } \\
\text { Metode }\end{array}$ \\
\hline Eksponensial Linier & 1564450485 & 3 \\
Dekomposisi & 510966679 & 1 \\
ARIMA $(0,1,1)$ & 876651753 & 2 \\
\hline
\end{tabular}

\section{Implikasi Hasil Peramalan bagi CV. Cihanjuang Inti Teknik}

Perusahaan yang sukses adalah perusahaan yang mampu mengendalikan segala bentuk ketidakpastian serta mampu menghadapi perubahan yang terus menerus. Perubahan yang terjadi dalam volume penjualan (menurun atau meningkat) pada CV. Cihanjuang Inti Teknik akan mempengaruhi perkembangan perusahaan tersebut. Oleh karena itu perusahaan perlu memahami dan menanggapi perubahan volume penjualan tersebut.

Berdasarkan hasil peramalan penjualan dengan ketiga buah metode, diperoleh hasil yang ber beda beda, yakni ada yang meningkat dan ada pula yang menurun. Selanjutnya berdasarkan konsep MSE, diperoleh bahwa metode yang terakurat adalah Metode Dekomposisi. Namun demikian, dalam prakteknya, perusahaan dapat mempertimbangkan juga dua metode yang lainnya sesuai dengan kondisi perusahaan saat akan memutuskan membuat peramalan penjualan bandrek. Oleh karena itu pembahasan selanjutnya akan dilakukan untuk kondisi peramalan penjualan yang meningkat maupun yang menurun.

Untuk mengantisipasi penjualan yang meningkat atau menurun, perusahaan perlu mempersiapkan perubahan dalam hal a. persediaan bahan baku, b. perencanaan produksi, c. persediaan anggaran, dan $\mathrm{d}$. perencanaan pemasaran. Hal ini perlu dilakukan demi kelancaran proses produksi bandrek. Hasil peramalan penjualan bandrek dapat digunakan perusahaan untuk :

a. Memperkirakan jumlah bahan baku yang dibutuhkan untuk memproduksi bandrek. Selanjutnya penjadwalan pembelian bahan baku perlu dilakukan agar terhindar dari keterlambatan pengiriman bandrek. Untuk mengantisipasi peningkatan penjualan, perusahaan dapat menambah pemasok jahe dan gula aren yang baru. Perusahaan juga dapat bekerja sama dengan petani daerah sekitar sehingga dapat menghemat biaya pengiriman dan biaya pemesanan. Jika kekurangan bahan baku maka dapat menyebabkan proses produksi terhenti, yang mengakibatkan keuntungan tertunda. Sebaliknya, kelebihan bahan baku dapat meningkatkan biaya penyimpanan dan menanggung risiko rusaknya bahan baku tersebut.

b. Memperkirakan jumlah jahe yang akan diproduksi untuk periode yang akan datang. Apabila peramalan penjualan meningkat, perusahaan dapat juga menambah tenaga kerja

c. Menghitung persediaan anggaran. Biaya-biaya yang perlu disiapkan adalah biaya untuk pembelian bahan baku, perawatan alat dan mesin, biaya produksi, pemasaran, administrasi dan upah tenaga kerja. Dengan demikian, perusahaan dapat menghitung perolehan laba dengan mengurangkan total biaya tersebut dari penerimaan.

d. Memperkirakan rencana pemasaran. Perusahaan saat ini sedang fokus untuk membuka agen dan distributor. Tetapi pelaksanaannya tidak mudah karena perusahaan kurang dikenal masyarakat. Hal ini disebabkan perusahaan kurang melakukan promosi. Akibatnya perusahaan sulit memasarkan bandreknya ke daerah baru. 


\section{SIMPULAN}

Berdasarkan hasil dan pembahasan, dapat diambil kesimpulan sebagai berikut: Pola data penjualan bandrek CV. Cihanjuang Inti Teknik selama tiga tahun (Juni 2011 hingga Mei 2014) memiliki unsur trend yang meningkat dan unsur musiman. Unsur trend terlihat dari penjualan yang cenderung meningkat setiap tahun, sedangkan unsur musiman terlihat dari pola data yang berulang setiap tahunnya, yaitu penjualan turun memasuki bulan puasa dan naik menjelang akhir tahun; 2. Peramalan volume penjualan bandrek CV. Cihanjuang Inti Teknik untuk satu tahun ke depan dengan menggunakan ketiga buah metode menunjukkan hasil yang berbeda-beda. Hasil peramalan dengan menggunakan metode eksponensial linier menunjukkan bahwa penjualan untuk satu tahun yang akan datang meningkat. Demikian pula hasil peramalan yang menggunakan metode dekomposisi, tetapi peningkatannya lebih besar. Sedangkan hasil peramalan dengan menggunakan ARIMA $(0,1,1)$ menunjukkan penjualan akan turun, dimana penurunannya lebih kecil dibandingkan dengan peningkatan pada metode Dekomposisi; 3. Kesalahan peramalan terkecil terdapat pada hasil peramalan yang menggunakan metode dekomposisi. Dengan demikian metode Dekomposisi merupakan metode yang paling akurat untuk meramalkan volume penjualan bandrek CV. Cihanjuang Inti Teknik

\section{DAFTAR PUSTAKA}

Arsyad, L. 1999. Peramalan Bisnis Edisi Pertama. Yogyakarta: BPFE-Yogyakarta
Assauri, S. 1984. Teknik \& Metoda Peramalan Penerapannya dalam Ekonomi \& Dunia Usaha. Edisi Satu. Jakarta: Lembaga Penerbit Fakultas Ekonomi Universitas Indonesia.

Herjanto, E. 2004. Manajemen Produksi dan Operasi. Jakarta: Grasindo.

Makridakis, Wheelwright dan Mc.Gee 1991. Metode dan Aplikasi Peramalan Jilid 1. Jakarta: Binarupa AKsara.

Nazir. 2003. Metode Penelitian. Jakarta: Penerbit Ghalia Indonesia

Prasetya, Herry, dan Fitri Lukiastuti, 2009. Manajemen Operasi. Yogyakarta: MessPress.

Rangkuti, F. 2005. Manajemen Persediaan, PT. Gramedia Pustaka Utama. Jakarta

Render, B dan Jay H. 2001. Prinsip-prinsip Manajemen Operasi. Jakarta: Empat.

Robert K. Yin, 2002. Case Study Research. Design and Methods. Edisi ketiga. Applied social research method series Volume 5. California: Sage Publications.

Yusuf, R R. 2002. Formulasi Karakteristik Kimia dan Uji Aktivitas Antioksidan Produk Minuman Tradisional Sari Jahe dan Sari Sereh. Skripsi. Fakultas Tehnologi Pertanian. Institut Pertanian Bogor. 